\title{
RMetS
}

\section{Erratum to 'Seasonal surface urban energy balance and wintertime stability simulated using three land-surface models in the high-latitude city Helsinki’}

\author{
P. Karsisto, ${ }^{\mathrm{a}, \mathrm{b}}$ C. Fortelius, ${ }^{\mathrm{b}}$ M. Demuzere, ${ }^{\mathrm{c}}$ C. S. B. Grimmond, ${ }^{\mathrm{d}}$ K. W. Oleson, ${ }^{\mathrm{e}}$ R. Kouznetsov, ${ }^{\mathrm{b}, \mathrm{f}}$ \\ V. Masson ${ }^{\mathrm{g}}$ and L. Järvi ${ }^{\text {a* }}$ \\ a Department of Physics, University of Helsinki, Finland \\ ${ }^{\mathrm{b}}$ Finnish Meteorological Institute, Helsinki, Finland \\ ${ }^{c}$ Department of Earth and Environmental Sciences, KU Leuven, Belgium \\ ${ }^{\mathrm{d}}$ Department of Meteorology, University of Reading, UK \\ ${ }^{\mathrm{e} N a t i o n a l ~ C e n t e r ~ f o r ~ A t m o s p h e r i c ~ R e s e a r c h, ~ B o u l d e r, ~ C O, ~ U S A ~}$ \\ ${ }^{\mathrm{f}}$ Obukhov Institute for Atmospheric Physics, Moscow, Russia \\ ${ }^{g}$ CNRM-GAME, Météo-France, CNRS, Toulouse and Grenoble, France
}

${ }^{\star}$ Correspondence to: L. Järvi, Department of Physics, P.O. Box 00014, University of Helsinki, Finland.

E-mail: leena.jarvi@helsinki.fi

The above article was originally published on Early View on 9 October 2015, and subsequently in volume 142 (issue 694): 401-417; DOI:10.1002/qj.2659.

In section 5.3 Sensible heat flux, the numbers of RMSE are wrong in the second paragraph. The text should remain the same but the numbers in brackets should be as follows:

CLM simulates the wintertime $\mathrm{Q}_{\mathrm{H}}$ best at Kumpula $\left(\mathrm{RMSE}=27 \mathrm{~W} \mathrm{~m}^{-2}\right)$, but overestimates $\mathrm{Q}_{\mathrm{H}}$ at Torni
$\left(\mathrm{RMSE}=73 \mathrm{~W} \mathrm{~m}^{-2}\right.$ ) particularly at night. Although SUEWS is able to predict the difference between the two sites, it underestimates nocturnal $\mathrm{Q}_{\mathrm{H}}$ at Torni and overestimates daytime $\mathrm{Q}_{\mathrm{H}}$ at Kumpula (RMSE of 46 and $32 \mathrm{~W} \mathrm{~m}^{-2}$ respectively). SURFEX underestimates $\mathrm{QH}_{\mathrm{H}}$ at both Torni and Kumpula (RMSE $=60$ and $33 \mathrm{~W} \mathrm{~m}^{-2}$, respectively) and is not able to predict the difference between the two sites in wintertime. 